\title{
AN ANALYSIS OF BOND MARKET LIQUIDITY AND REAL SECTOR OUTPUT IN SELECTED AFRICAN ECONOMIES
}

\section{Patrick O. Eke ${ }^{1}$, Kehinde A Adetiloye ${ }^{2}$, Esther O Adegbite ${ }^{3}$}

\author{
1 Covenant University and Lagos State University, Department of Banking and Finance, Nigeria, ORCID: 0000-0003- \\ 4895-4199, patrick.eke@covenantuniversity.edu.ng; \\ 2 Covenant University, Department of Banking and Finance, Nigeria, ORCID: 0000-0002-7171-0793, \\ kehinde.adetiloye@covenantuniversity.edu.ng (corresponding author); \\ 3 University of Lagos, Department of Finance, Nigeria, femifunmi1981@gmail.com.
}

\begin{abstract}
There is increasing traction in the literature on the activities of the secondary securities' market especially with bonds on financial development, with little known on its functional linkage to real sector growth. Following popular theories on bond financing, this study sought to fill this gap by examining if functional tie exists between the secondary bond markets and real sector output among fourteen African countries with functional bond markets and complete data. Among the variables adapted for use are real gross domestic product per capital, corporate bond issues, industrial output, corporate bond turnover, financial education, electricity consumption and institutional quality. The study tested through unit roots to augmented Toda-Yamamoto non-causality and cointegration approach to investigate both the short- and long-term relationships among the different variables. A priori, it was expected that market information would engender capital raising through bond issues and fund allocation. The study however, discovers that corporate bond turnover does not cause industrial output growth, neither does it cause corporate bond issue. An important short run result indicates that the impact of financial education is gradually being felt in the bond markets. For most of the long-run relationships, the study accepted the Null hypothesis. This implies that the investing public do not absorb the usefulness of the market information, which may explain the thinness and shallowness of African corporate bond market overtime. The liquidity signalling effects is however found to influence regulatory institutional quality in the long-run. An accelerated financial market liberalization and tax incentives for private sector provision of market infrastructure are recommended among others for improvement in the African bond markets investigated, among others.
\end{abstract}

Keywords: African economies, bond issuing market; bond market liquidity, real sector output growth.

JEL Classification: N27, C40, E23.

APA Style Citation: Eke, P. O., Adetiloye, K. A., \& Adegbite, E. O. (2020). An Analysis of Bond Market Liquidity and Real Sector Output in Selected African Economies. E\&M Economics and Management, 23(4), 166-182. https://doi.org/10.15240/tul/001/2020-4-011

\section{Introduction}

The debate on development of the bond market as major channel of industrial finance is gaining traction in many African economies. The secondary arm of the market, aside from the liquidity window it provides for investors in the primary market, additionally creates information linkage by fostering capital formation for prospective investors and producers that require capital to meet their investment opportunities, assisting in the allocation and operational efficiency of the capital market. Except if the market remains thin, overtime, liquidity in the market becomes more visible in the economy's financial architecture, as it ignites market dynamism in the financial services linkage 
with other sectors of the economy. Liquidity is a pre-requisite to deepening the bond market, conditioned on information availability to ease asset valuation. The rapidity and randomness of information is what actually distinguishes capital market functionality and efficiency (Wijst, 2013).

The bond market is a time varying investment channel (Grishchenko et al., 2015). Overall, its development depends on many factors, particularly the viability of the primary (new issue) market whose values transmit to the liquidity of the secondary market (FMW, 2013; Andriansyah \& Messani, 2014). The primary bond market helps in the performance of dual function of improving savings culture and investment simultaneously. The secondary market in reverse provides foundation for price discovery for subsequent capital issues (Sorensen \& Whitta-Jacobsen, 2010). Nevertheless, the primary bond market is a crucial variable for capital formation and industrial investment.

In general, corporate bond finance option offers multiple benefits to the issuer, the investor, and serves the public interest, including mutual gains to global investors (Tendulkar, 2015). The development of an economy's new bond issue market however depends on available institutions and their efficiency. These include regulators and the judicial institutions and other factors (Eke et al., 2018). The need to curtail the deterrents of 'information asymmetry', towards boosting the direct finance culture for industrial growth cannot be over emphasized. A clear advantage in favour of the direct financing is that no transaction cost affects the investor unlike in the indirect market where intermediation fee has to be paid. Although, the primary market enables flow of capital to firms, however, the pricing, marketability and liquidity roles of the secondary market makes this segment of the capital market much larger and a pull instrument to the primary market development.

Is there ease of securities trading in the selected African economies, and what gains may accrue to the regional economies with an efficient secondary market? The ease of being able to fall back to investment for cash when the need arises and exchangeable is a fundamental hallmark in the investment industry. Many studies have found out that African bond markets are weak and shallow, as facilitating institutions and instruments are rather few, with low capacity, except perhaps

\section{Fig. 1: African economies' bond market size (US\$ million) 2009-2019}

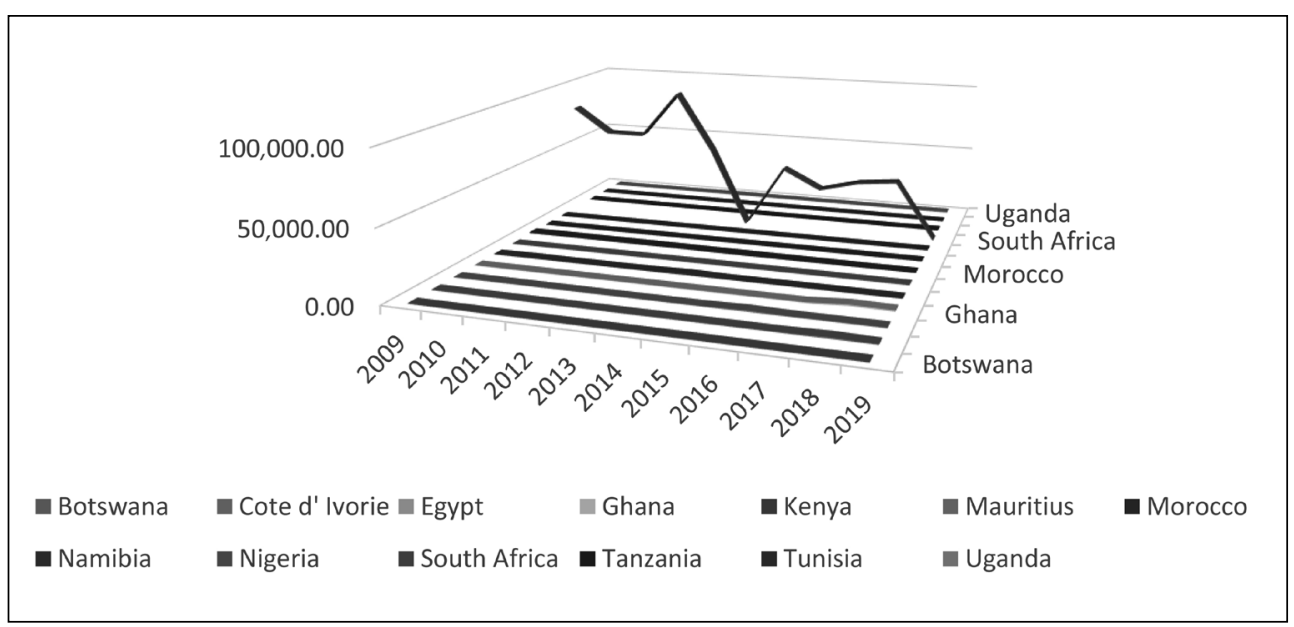

Source: Secondary market performance of selected economies. Annual corporate bond traded value data is obtained from African Securities Exchange Association (ASEA) statistics from 2015 to 2019, Annual Report \& Statistics, 2014, http://www.african-exchanges.org and Year Book 2009, www.africansea.org. 
for South Africa (Mu et al., 2013; Adelegan \& Razewicz-Bak, 2009). In particular, the limited extent to which bond securities holders can market their instruments affects the efficiency of the markets, which may have constrained the development of the issue market.

The size of the bond markets in the economies under study are rather small compared to global peers, however with the emergence of the over-the-counter (OTC) exchanges in the continent, improvements would be experienced, such as the improved state of the Nigerian market, upon emergence of the Financial Market Dealer Quotation (FMDQ) in 2013. The ZAR X OTC Exchange has also debuted in South Africa, in 2016. Though it has eased somehow in most African economies, liquidity is still very much priced (Assefa \& Mollick, 2014). Presented in Fig. 1 is the performance of the secondary bond market, in which except for South Africa, the 15 other economies recorded below ten billion US dollars turnover per annum from 2009-2018.

Objectively, this paper seeks to investigate if there is a significant relationship between the secondary corporate bond market and industrial output growth. The hypothesis to be tested says that there is no significant relationship between corporate bond market turnover and industrial output in the selected African economies. The subsequent sections of the paper are as follows: literature review is followed by theoretical framework and methodology, estimated results, discussion of findings, conclusion and recommendations.

\section{Literature Review}

The understanding that African financial markets are shallow because the deposits that creates loans are all too short-termed in the banking market to allow real investment lending that leads to development occur. Though the markets are shallow with few instruments, there are some activities going on in them (Adetiloye et al., 2017). Bod'a and Zimková (2018) discussed the case of Slovak banking sector where smaller banks and branches of the foreign banks seem more efficient at intermediation than the domestic ones. With the general nature of market structure in the African economies especially the major economies being oligopolistic in structure, the real sector faces liquidity challenges in their financing of working capital. The consensus in the literature is that: at the beginning of development, entrepreneurs use more of their savings and later financing is more bank-driven, while sooner, upon greater development and the credit system, financing becomes a derivative of the real sector (Patrick, 1966; Goldsmith, 1969). Given the quest for the corporate firm expansion towards maximising market position, the capital structure decision of what optimal method of finance begins with a process that may impact on the firm's value and marketability (Van Horne \& Dhamija, 2012; Olowe, 2011). The Bank for International Settlement (BIS) through Basel III has been discouraging banks form inter-bank lending activity in order to force them to lend to the real sector and ultimately to the bond market as it engenders better financial system stability (Kinyigi, 2010).

In theoretical context, the channels that the bond market influence the real sector is through the market efficiency theory. In an efficient capital market, borrowers and lenders are assumed to allocate investment funds optimally, as scarce savings are expected to return optimal marginal rate, adjusted for risks. The theory claims that securities prices absorb all relevant information, such that prices are often in equilibrium. If however, they deviate, that is under or overvalued, then the activities of market arbitrager sets in to restore equilibrium.

The transmission through stock price movement also impact on the aggregate real investment, as it provides the bases of the price of fresh capital issue. Cecchetti (2008) contends that the stock price movements and the real investment relations is achieved through the traditional interest-rate channel's influence on investment and consumer durable expenditure or alternatively, sizable wealth effect on consumption. Upon a fall in real interest rate, stock prices increase, financing becomes cheaper (since cost of the firm's marginal or new profitable investment would still be relatively constant with its internal rate of return). Firms are then motivated to raise funds to expand capacity by issuing new shares or bonds in the primary capital market. However, significant empirical investigations, have questioned the significance of the interest rate channel to wealth effects as provided in Bernanke and Blinder (1988), Bernanke and Gertler (1990) and Reichlin (2004).

The influence of foreign portfolio fund in the capital market of most of these economies 
cannot be wished aside. Both the investment and return quotient are significant in the flows of capital. Piljak and Swinkels (2017) show that the correlation between frontier market government bonds and corporate and high-grade bonds in advanced economies is substantially high. This limits the possibility of diversification, this is in spite of the high interest rate gap in the economies that encourage oligopolistic banks unusual profiteering from non-core financial intermediation (Eke et al., 2017).

Liquidity in bond markets generally could be an issue, but in thin and shallow African bond markets present another set of problems. It seems that without foreign capital inflows, illiquidity will pervade the markets. Thus Darvas (2012), intones that the inflows of capital to the bond markets that create liquidity affect the real effective exchange rate of the countries' currencies, which has been caused more by capital account openness than improvement in trade (Esqueda et al., 2012). The study by Assefa and Mollick (2014) found that liquidity and stock returns is easily correlated African markets with the tests excluding South Africa having the most developed of the stock market in the continent.

\section{Theoretical Framework and Methodology}

\subsection{Theoretical Framework}

From the information theory, what is the level of information content of the real sector in the secondary bond market transmitted to the issue market? Copeland and Weston (1992) denote information structure as a set of messages that produce gains or value $V(\eta)$ as follows:

$$
V(\eta) \equiv \sum_{m} q(m) M \underset{a}{A} X \sum_{e} p(e \backslash m) U(a, e)-V\left(\eta_{0}\right)
$$

where:

$q(m)=$ the marginal propensity of receiving a message $m$;

$p(e \mid m)=$ the conditional probability of an event $e$, given a message $m$;

$U(a, e)=$ the utility resulting from an action $a$ if an event $e$ occurs; called the "benefit function";

$V\left(\eta_{0}\right)=$ the expected utility of the decision maker without the information.

Formula 1 portends that a decision maker will evaluate an information structure (set of messages) by choosing an action capable of maximizing the individual's expected utility as messages arrive. From formula 1, for each possible message an "optimal action" that produces a solution is determined as follows:

$$
M \underset{a}{A} X \sum_{e} p(e \backslash m) U(a, e)
$$

By weighing the expected utility of each optimal action by the probability, $q(m)$, the decision maker knows the expected utility of the entire set of information called the utility value or the expected utility of an information set $V\left(\eta_{0}\right)$.

\section{Data}

The study adopts a panel data set. An observation is studied in pair of entities and time such that in variables $x_{i t}, y_{i t}, i$ and $t$, subscripts denote individual country and time respectively. The period of study is from 1995-2018. It is an unbalanced panel data set as some countries have omitted observations in certain years, that is:

$$
\left\{x_{i t}, y_{i t}\right\}: \text { for } i=1 \ldots, N ; t=\underline{t_{i}}, \ldots, \overline{t_{i}}
$$

Secondary data is used covering 1995-2018 and sourced from World Development Indicators (WDI), International Finance Corporation (IFC), Bank for International Settlement (BIS), International Organization of Securities Commissions (IOSCO), African Securities Exchanges Association (ASEA), United Nations Development Programme Statistics, Central Bank of Nigeria's Statistical bulletin and National Bureau of Statistics. The arrangements of the source of each variable is presented in Tab. 1.

There are 54 countries on the African continent. However, following the dearth of corporate bond market development and the existence of observation omissions, the study is limited to sixteen African countries that have corporate bond issues being traded on their Exchanges as at 2014 (ASEA, 2014). The summed size of the selected African capital markets is approximately $97.6 \%$ of African Stock Market Capitalization as at 2019 (ASEA, 2014). These are Botswana, Cameroon, Cote d' Ivoire, Egypt, Ghana, Kenya, Malawi, Mauritius, Morocco, Namibia, Nigeria, Rwanda, South Africa, Tanzania, Tunisia and Uganda. However, due to incomplete data from Malawi, Rwanda and Uganda, those countries dropped, thereby reducing the sample size to thirteen. 
Tab. 1: Description of variables, data sources with justification

\begin{tabular}{l|l|l}
\multicolumn{1}{c|}{ Variable description } & \multicolumn{1}{c|}{ Type/Source } & \multicolumn{1}{c}{ Literature justification } \\
\hline$I 0=$ Ind. output value added & World Bank & $\begin{array}{l}\text { UNIDO (2014), WEF (2013), } \\
\text { Adebiyi (2005) }\end{array}$ \\
\hline$C b t=$ Corporate bond turnover & BIS*/BM $^{* *} /$ ASEA $^{* * *}$ & Tendulkar (2015) \\
\hline$C b i=$ Corporate bond issued & BIS*/BM $^{* *}$ & Tendulkar (2015), Asogwa (2005) \\
\hline$R p i=$ Real Gdp per capita & World Bank & Akinlo and Owoyemi (2012) \\
\hline $\begin{array}{l}\text { Fed }=\text { Financial education } \\
\text { (measured by ratio of expenditure } \\
\text { on education) }\end{array}$ & World Bank & $\begin{array}{l}\text { Grossman and Helpman (1994), } \\
\text { Pack (1994), Mun Heng (2015) }\end{array}$ \\
\hline $\begin{array}{l}\text { Iqx }=\text { Institutions' quality: } \\
\text { Regulatory quality, rule of law, } \\
\text { govt. effectiveness }\end{array}$ & $\begin{array}{l}\text { Worldwide Governance } \\
\text { Indicators (2018): } \\
\text { www.govindicators.org }\end{array}$ & $\begin{array}{l}\text { Ayala et al. (2015), Djankor et al. } \\
(2007)\end{array}$ \\
\hline Elc $=$ Electricity consumption & World Bank & Hye and Riaz (2008) \\
\hline
\end{tabular}

Source: own

Note: ${ }^{*}$ BIS = Bank for International Settlement; ${ }^{* *} B M=$ Bond markets of sampled countries; ${ }^{* *} A S E A=$ African Securities Exchanges Association.

\section{Technique of Estimation}

The study is built on the trivariate. The applicable empirical test for the study is on the bond market liquidity efficiency transmission to the real sector. Thus a dynamic relationship is expected, detailed in an augmented TodaYamamoto technique. The Toda-Yamamoto (1995) discusses the long-run regression by extending granger causality methodology to handle causal relation models in a VAR environment involving non-uniform level of stationarity among time series data set. Engle and Granger (1987) point out that inference from non-stationary and co-integrated variables' coefficients with the standard granger causality test results thereof may be invalid. The summarized specification of the original Toda and Yamamoto framework for $Y t$ and $X t$ series stated with panel notation is provided below:

$$
\begin{aligned}
& Y_{i t}=a+\sum_{j=1}^{m+d} \phi_{j} Y_{i t-i}+\sum_{k=1}^{n+d} \varpi_{k} X_{i t-j}+\varepsilon_{Y i t} \\
& X_{i t}=a+\sum_{j=1}^{m+d} \varphi_{j} X_{i t-1}+\sum_{k=1}^{n+d} \delta_{k} Y_{i t-1}+\varepsilon_{X i t}
\end{aligned}
$$

where $d$ represents maximum order of integration of the variable in the system, $m$ and $n$ are optimal lag of $Y t$ and $X t$. The random error $\varepsilon$ is assumed white noise. This study extends its dynamic short run form by an innovation. It introduced into the TY procedure the short run dummies into the original TY long-run model. Langrage multiplier (LM) serial correlation test was carried out. Additional diagnostic test is applied on the VAR residuals, i.e. the residual diagnostics test; and the co-integration long-run test.

The model adopts modified Wald test, whose statistic for the $Y$ formula is presented below:

$$
F=\frac{\left(R s s_{R Y}-R s s_{U Y}\right) / K}{R s s_{U Y} /(N-K)}
$$

where $K$ represents the number of estimated coefficients. Using the F-test and Chi-squared statistics, the null hypothesis of no co-integration relationship is defined as: $H_{0}=\delta_{1}=\delta_{2}=0$ against alternative hypothesis that $H_{1}=\delta_{1}=\delta_{2}=0$ of the presence of co-integration.

\subsection{Model Specification}

In the context of the hypothesis, the model is specified implicitly in formula 7 such that in the African region, industrial output (lo) is a linear function of corporate bond turnover (Cbt) as prima variable. Other control variables in the model are financial education/knowledge 
(Fed) proxied by human capital development to capture the extent of financial information valuation, dissemination, and interaction. The Fed is measured by percentage of government expenditure on education; Institutional regulatory quality (Iqx) which combines quality institutions, rule of law and governance effectiveness. The a priori expectations are stated below:

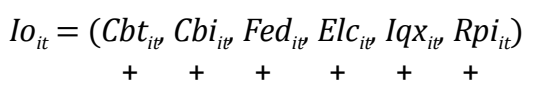

The standard form of the dynamic panel is expressed as:

$$
y_{i t}=\phi y_{i, t-1}+X_{i t}^{\prime} \beta+u_{i t}
$$

where $u_{i t}=\mu_{i}+\varepsilon_{i t}$

$\mu_{i}$ stands for each country's specific time invariant level effects; while $\varepsilon_{i t}$ is the cross country and time effects. To overcome the inherent problem embodied in formula 7 , the generalized method of moment (GMM) suggests first differencing method to transform formula 7 , the fixed country-specific effect is eliminated (Arellano \& Bond, 1991).

$$
\begin{aligned}
& u_{i t}-u_{i, t-1}=\left(\mu_{i}-\mu_{i}\right)+\left(\varepsilon_{i t}-\varepsilon_{i, t-1}\right)= \\
& =\varepsilon_{i t}-\varepsilon_{i, t-1}
\end{aligned}
$$

In standard explicit form, the dynamic multivariate Panel Granger-VAR system is as follows in formulas 11 through to 14 :

$$
\begin{aligned}
& \Delta I o_{i t}=\alpha_{1}+\sum_{j=1}^{P} \theta_{1 j} \Delta C b t_{i t-j}+ \\
& +\sum_{j=1}^{P} \delta_{1 j} \Delta C b i_{i t-j}+\sum_{j=1}^{P} \varphi_{1 j} \Delta F e d_{i t-j}+ \\
& +\sum_{j=1}^{P} \psi_{1 j} \Delta E l c_{i t-j}+\sum_{j=1}^{P} \xi_{1 j} \Delta I o_{i t-j}+ \\
& +\sum_{j=1}^{P} \gamma_{1 j} \Delta R p i_{i t-j}+\sum_{j=1}^{P} \lambda_{1 j} \Delta I q x_{i t-j}+\varepsilon_{i t},
\end{aligned}
$$

$$
\begin{aligned}
& \Delta R p i_{i t}=\alpha_{7}+\sum_{j=1}^{P} \theta_{7 j} \Delta C b i_{i t-j}+ \\
& +\sum_{j=1}^{P} \delta_{7 j} \Delta C b t_{i t-j}+\sum_{j=1}^{P} \varphi_{7 j} \Delta F e d_{i t-j}+ \\
& +\sum_{j=1}^{P} \psi_{7 j} \Delta E l c_{i t-j}+\sum_{j=1}^{P} \xi_{7 j} \Delta I o_{i t-j}+ \\
& +\sum_{j=1}^{P} \gamma_{7 j} \Delta R p i_{i t-j}+\sum_{j=1}^{P} \lambda_{7 j} \Delta \operatorname{Iqx} x_{i t-j}+\varepsilon_{i t},
\end{aligned}
$$

where: $\theta, \delta, \varphi, \psi, \xi, \gamma$, and $\lambda$ are unknown parameters; $\alpha_{1-5}$ are constant terms; the individual country effects are captured in $\mu_{1-5}$; $\varepsilon_{i t}$ is the residual, white noise (idiosyncratic) compliant for each formula. Alternatively, the VECM framework that allows for multiple cointegrating vectors, with each explanatory variable bearing its speed-of-adjustment parameter can be represented as:

$$
\begin{aligned}
& \Delta Y_{t}=\alpha+\sum_{1=i}^{p} \Gamma_{i} \Delta Y_{t-i}+\Pi e_{t-i}+\varepsilon_{t} \\
& \Gamma=\tau \beta^{\prime}
\end{aligned}
$$

where $Y$ represents vector of variables listed in formula $8-14 ; \tau$ represents a matrix of speed of adjustment parameters, $\beta$ represents matrix of co-integrating vectors, $\varepsilon$ is vector of error terms.

\section{Estimation Results and Discussion}

\subsection{Time Series Analysis}

To determine the level of stationarity, within the context of heterogeneous panel, the study uses three panel unit root processing techniques. That is, the study assumes the common unit root based statistics, the Levin, Lin and Chu (LLC); and we assume individual or entity based unit root statistics, Im, Pesaran and Shin (IPS) and ADF-Fisher Chi-Square. A panel data unit root appears to be more complex than the time series due to the heterogeneous nature in panel data. Therefore, this study places overriding priority on the IPS test for its superiority in handling heterogeneities among entity unit roots in panel.

Presented in Tab. 2 below is the level of stationarity of the variables employed in the 


\begin{tabular}{|c|c|c|c|c|c|c|c|c|c|}
\hline \multirow[b]{2}{*}{$\begin{array}{l}\text { Variab- } \\
\text { les }\end{array}$} & \multicolumn{2}{|c|}{$\begin{array}{l}\text { Common unit root } \\
\text { process assumed }\end{array}$} & \multicolumn{7}{|c|}{ Country unit root process assumed } \\
\hline & LLC test & Prob. & IPS test & Prob. & $\begin{array}{l}\text { ADF- } \\
\text {-FCs }\end{array}$ & Prob. & PP & Prob. & $\begin{array}{l}\text { Inte- } \\
\text { grati- } \\
\text { on }\end{array}$ \\
\hline 10 & -4.1378 & $0.000^{*}$ & -5.6078 & $0.000^{*}$ & 88.1875 & $0.000^{*}$ & 298.669 & $0.000^{*}$ & $\mathrm{I}(0)$ \\
\hline $\mathrm{Cbt}$ & -4.3364 & $0.000^{*}$ & -8.4089 & $0.000^{*}$ & 120.792 & $0.000^{*}$ & $1,655.7$ & $0.000^{*}$ & $\mathrm{I}(1)$ \\
\hline Elc & -7.2303 & $0.000^{*}$ & -7.4235 & $0.000^{*}$ & 113.74 & $0.000^{*}$ & 455.46 & $0.000^{*}$ & $\mathrm{I}(1)$ \\
\hline Fed & -11.7963 & $0.000^{*}$ & -10.189 & $0.000^{*}$ & 173.05 & $0.000^{*}$ & 299.284 & $0.000^{*}$ & $\mathrm{I}(1)$ \\
\hline Rpi & -5.8756 & $0.000^{*}$ & -5.5396 & $0.000^{*}$ & 86.786 & $0.000^{*}$ & 130.831 & $0.000^{*}$ & $\mathrm{I}(1)$ \\
\hline $\operatorname{lqx}$ & -5.3367 & $0.000^{*}$ & -8.979 & $0.000^{*}$ & 132.37 & $0.000^{*}$ & $2,865.12$ & $0.000^{*}$ & $\mathrm{I}(1)$ \\
\hline $\mathrm{Cbi}$ & -4.3405 & $0.000^{*}$ & -4.101 & $0.000^{*}$ & 61.863 & $0.000^{*}$ & 120.46 & $0.000^{*}$ & $I(0)$ \\
\hline
\end{tabular}

Source: output of the variables

Note: * indicates significance at 0.01 .

study. Institutions regulatory quality (Iqx) is a level variable; Industrial output (lo), corporate bond issue (Cbi), and real per capita income (Rpi) are first difference variables; while sovereign bond issue (Sbi), corporate bond turnover (Cbt) and financial education (Fed), are second difference variables. The outcome of these tests influence to a large extent the Toda-Yamamoto (TY) estimation techniques, augmented for the short run result as employed in the analyses.

\section{Correlation Analysis}

The purpose of this sub-section is to reveal the preliminary relationship among the variables while simultaneously guarding against error of multicollinearity (Asteriou \& Hall, 2011). From Tab. 3 industrial output (Io) growth is negatively correlated with corporate bond turnover (Cbt) by $1 \%$; with energy consumption (Elc) by $31 \%$; with institutional quality (Iqx) by $9 \%$; with real per capita income (Rpi) by $23.5 \%$, and with corporate bond issues (Cbi) by $4 \%$; however, 10 is positively correlated with financial education (Fed) by $9.8 \%$. The negative correlation outcomes between the dependent variable (lo) and the five variables are however against the expectation of the study's a priori. It may suggest the poverty of industrial output growth in African economies.

In line with a priori, Cbt is positively correlated with corporate bond issue ( $\mathrm{Cbi}$ ) and real per capita income (Rpi) at moderate rates by $22 \%$ and $18 \%$ respectively. The $C b t \leftrightarrow C b i$ positive nexus does not however transmit to improving lo growth as both variables are negatively correlated with $l o$ in the respective economies. It may imply that the bond funds are not being efficiently managed for industrial production. Moreover, investing in corporate bond as an inflation risk hedging strategy is evident in the $22 \%$ positive correlation between the $\mathrm{Cbt}$ and real per capita income (Rpi). It suggests increased activities in the secondary transfer market among investors and the quest for capital gain on bond investments, which the financial education (Fed) positive correlation with $\mathrm{Cbt}$ at $10 \%$ may have affirmed.

Institutions regulatory quality (Iqx) has positive correlation with corporate bond turnover (Cbt) at $14 \%$. The outcome suggests that institutions that govern capital market development such as the capital market regulators and allied institutions like the legal and judicial institutions need to engage in investors' protection and establish more opportunities for improved secondary market trading.

\section{Lag Length Order}

Lag length selected for the set of variables is based on the criteria chosen by majority of the tests. In this case, the combined test methods chose lag three as optimal, as presented in Tab. 4. However, the test result is influenced down to two given the outcome of the LM serial 


\section{Tab. 3: $\quad$ Correlation matrix table}

\begin{tabular}{l|c|l|l|l|l|l|l} 
& Io & Cbt & Elc & Fed & Iqx & Rpi & Cbi \\
\hline lo & 1 & & & & & & \\
\hline Cbt & -0.0105 & 1 & & & & & \\
\hline Elc & -0.3145 & 0.2275 & 1 & & & & \\
\hline Fed & 0.0980 & 0.1036 & 0.1766 & 1 & & & \\
\hline Iqx & -0.0945 & 0.1408 & 0.4827 & 0.1565 & 1 & & \\
\hline$R p i$ & -0.2353 & 0.2199 & 0.8642 & 0.1535 & 0.4634 & 1 & \\
\hline$C b i$ & -0.0444 & 0.0815 & 0.2018 & 0.0727 & 0.2416 & 0.2703 & 1 \\
\hline
\end{tabular}

Source: own

\section{Tab. 4: Optimal lag}

\begin{tabular}{c|c|c|c|c|c|c} 
Lag & Log L & LR & FRE & AIC & SC & HQ \\
\hline 0 & $-2,418.67$ & NA & 0.0201 & 15.9584 & 16.0440 & 15.9926 \\
\hline 1 & -539.26 & $3,659.89$ & $1.18 \mathrm{e}-07$ & 3.9162 & 4.6009 & 4.1902 \\
\hline 2 & -377.414 & 307.73 & $5.64 \mathrm{e}-08$ & 3.1737 & $4.4576^{*}$ & $3.6873^{*}$ \\
\hline 3 & -292.708 & $157.15^{*}$ & $4.46 \mathrm{e}-08^{*}$ & $2.9388^{*}$ & 4.8218 & 3.6921 \\
\hline 4 & -257.905 & 62.967 & $4.91 \mathrm{e}-08$ & 3.0322 & 5.5143 & 4.0252 \\
\hline
\end{tabular}

Source: own

Note: $L R=$ sequential modified LR test statistic (each test at $5 \%$ level); FPE = Final prediction error; AIC = Akaike information criterion; SC = Schwarz Information Criterion; $\mathrm{HQ}=$ Hannan-Quinn information criterion. ${ }^{*}$ denotes lag order selected by the criterion.

correlation test (Tab. 4) which reveals that the model is free of serial correlation at order two.

\section{Empirical Results}

\section{Short- and Long-run Effects}

We adopt the augmented Toda-Yamamoto (ATY) technique to treat the hypothesis that seeks to establish if there is a link between the secondary market in corporate bond and industrial output growth rate in the short-run and long-run in the selected African economies. There is a thought in the financial literature that the activities of the secondary market can ignite respective firms to raise more bonds to upscale productivity (Goldstein et al., 2019). Tab. 5 shows the short-term (dynamic) results for the multivariate model. Except for the corporate bond turnover (Cbt) formula that has standard negative short-run coefficient, which indicate that the joint influence of explanatory variables flows to the dependent variable, and that the formula converges to equilibrium in the long-term. However, the Industrial output (Io), electricity consumption (Elc), financial education ( $F d v$ ) a proxy for financial awareness, institutional quality index (Iqx), real per capita income (Rpi) and the corporate bond issue (Cbi) are not rightly signed, which suggest that the formulas do not converge, and would be explosive in the long-term. The result may indicate the relative uncertainty and poor performance of the non-converging variables, and hence lack of effective support to the real sector growth potential in these economies.

On the individual variable long-term causality relations in Tab. 6 and in line with the objective of null hypothesis for this study that no significant causality flow from corporate bond turnover (Cbt) to industrial output (Io) growth is upheld, as the Cbt does not influence lo in the long-term. The same outcome is observed from corporate bond issue (Cbi) to $\mathrm{lo}$. However, significant unidirectional causal flow is noticed from Io to both $\mathrm{Cbi}$ and $\mathrm{Cbt}$, which suggests that the influence of the structure of financial system (that had been of short-end 
bank based) may be weighing against the bond market capacity. The economies are dominated by oligopolistic banking structures (Ojo, 2010) and industrial output sector depends largely on bank financing.

Bidirectional causal flow is noticed between corporate bond turnover (Cbt) and institutional quality index (Iqx), which imply that both variables can synergise for the development of the bond market capacity. While quality institution spurs confidence and trust among both the retail and institutional investors, an increase in corporate bond turnover can positively improve institutional regulatory quality - under the information role of the secondary market price theory (Bond et al., 2011). By this finding, it can be concluded that the information role of the secondary bond market influences institutional regulations only, while its role in spurring corporate issue, which indirectly should increase industrial output growth is not being felt in bond markets.

The dynamic relationship result also reveals that financial education (Fed) is unidirectional causing flow to $\mathrm{Cbt}$, which suggests the increase in the peoples' financial knowledge is being felt in the secondary bond market. However, the negative relationship flow from Cbt to Fed may suggest that the market "noise" may have no effect towards educating the peoples, and hence has not been attractive to investors.

Moreover, being a dynamic study, the bond market turnover (Cbt) does not have long-run bi-directional causal relationship with substantial numbers of exogenous variableselectricity consumption (Elc) and real per capita income (Rpi). Though contemporary findings that market liquidity impact on corporate issues in the bond market is scarce, nevertheless, few results exist in the equity market. The result does not agree with the findings of Hoschi et al. (1991), Demirguc-Kunt and Levine (1996), Andriansyah and Messinis (2014); and for bond market, Harrison (2002). Andriansyah and Messinis (2014) used dynamic panel regression technique for their study of the equity market in 54 OECD and non-OECD economies and find that the secondary market liquidity influences capital issues of firms from 1995-2010. Using two sets of industrial firms as case study, Hoschi et al. (1991) find that industrial investment is more sensitive to market liquidity in Japan. Harrison (2002) reveals that bond market size is a function of market liquidity.

\section{Tab. 5: Short-run (dynamic) causality results}

\begin{tabular}{l|c|c|c|c|l}
\hline $\begin{array}{l}\text { Dependent } \\
\text { variable }\end{array}$ & $\begin{array}{c}\text { Optimal lag } \\
\text { order of } \\
\text { explanatory } \\
\text { variables }\end{array}$ & $\begin{array}{c}\text { Coefficient: } \\
\text { short run } \\
\text { residual }\end{array}$ & Std. error & Prob. & Outcome \& implication \\
\hline lo & 2 & 0.0850 & 0.2373 & 0.7204 & $\begin{array}{l}\text { No convergence towards } \\
\text { equilibrium }\end{array}$ \\
\hline Cbt & 2 & $-0.9316^{* * *}$ & 0.2903 & 0.0015 & $\begin{array}{l}\text { Joint influence of } \\
\text { explanatory variables flow } \\
\text { to the dependent variable } \\
\text { \& converges to equilibrium }\end{array}$ \\
\hline Elc & 2 & $0.6734^{* *}$ & 0.3107 & 0.0311 & $\begin{array}{l}\text { No convergence towards } \\
\text { equilibrium }\end{array}$ \\
\hline Fed & 2 & 0.0065 & 0.2489 & 0.9793 & $\begin{array}{l}\text { No convergence towards } \\
\text { equilibrium }\end{array}$ \\
\hline Iqx & 2 & 0.4466 & 0.3201 & 0.1640 & $\begin{array}{l}\text { No convergence towards } \\
\text { equilibrium }\end{array}$ \\
\hline$R p i$ & 2 & $0.5079^{*}$ & 0.2966 & 0.0880 & $\begin{array}{l}\text { No convergence towards } \\
\text { equilibrium }\end{array}$ \\
\hline Cbi & & 0.2398 & 0.1985 & 0.2280 & $\begin{array}{l}\text { No convergence towards } \\
\text { equilibrium }\end{array}$ \\
\hline
\end{tabular}




\begin{tabular}{|c|c|c|c|c|c|c|c|}
\hline \multirow{3}{*}{$\begin{array}{l}\text { Null hypothesis } \\
t \text { does not cause lo } \\
\text { does not cause Cbt }\end{array}$} & \multirow{3}{*}{$\begin{array}{l}\text { Coeff. } \\
0.0007 \\
0.5248^{\star} \\
\end{array}$} & \multirow{3}{*}{$\begin{array}{c}\text { Std. error } \\
0.0005 \\
7.9605\end{array}$} & \multirow{3}{*}{$\begin{array}{l}\begin{array}{c}\text { Causality } \\
\text { flowl } \\
\text { cointegration }\end{array} \\
\text { no causality } \\
\mathrm{lo} \rightarrow \mathrm{Cbt}\end{array}$} & \multicolumn{4}{|c|}{$\begin{array}{l}\text { MWald test ( } p \text { lag order) } \\
\text { value (prob. value) }\end{array}$} \\
\hline & & & & \multicolumn{2}{|c|}{$\chi^{2}$ stat. } & \multicolumn{2}{|c|}{ F-stat. } \\
\hline & & & & $\begin{array}{r}1.626 \\
17.024\end{array}$ & $\begin{array}{l}(0.443) \\
(0.000)\end{array}$ & $\begin{array}{l}0.813 \\
8.512\end{array}$ & $\begin{array}{l}(0.444) \\
(0.000)\end{array}$ \\
\hline $\begin{array}{l}\text { Cbi does not cause lo } \\
\text { lo does not cause } \mathrm{Cbi}\end{array}$ & $\begin{array}{r}0.0002 \\
20.060^{*}\end{array}$ & & $\begin{array}{l}\text { no causality } \\
\mathrm{lo} \rightarrow \mathrm{Cbi}\end{array}$ & $\begin{array}{r}0.558 \\
14.175\end{array}$ & $\begin{array}{l}(0.756) \\
(0.000)\end{array}$ & $\begin{array}{l}0.279 \\
7.087\end{array}$ & $\begin{array}{l}(0.756) \\
(0.000)\end{array}$ \\
\hline $\begin{array}{l}\text { lqx does not cause lo } \\
\text { lo does not cause lqx }\end{array}$ & $\begin{array}{l}0.0152 \\
0.1649^{*}\end{array}$ & $\begin{array}{l}0.0171 \\
0.2385\end{array}$ & $\begin{array}{l}\text { no causality } \\
\text { lo } \rightarrow \text { Iqx }\end{array}$ & $\begin{array}{l}0.898 \\
23.24\end{array}$ & $\begin{array}{l}(0.638) \\
(0.000)\end{array}$ & $\begin{array}{c}0.449 \\
11.62\end{array}$ & $\begin{array}{l}(0.638) \\
(0.000)\end{array}$ \\
\hline $\begin{array}{l}\text { Cbt does not cause lqx } \\
\text { lqx does not cause Cbt }\end{array}$ & $\begin{array}{l}0.0003^{*} \\
0.5483^{*}\end{array}$ & $\begin{array}{l}0.0002 \\
7.961\end{array}$ & $\begin{array}{l}\mathrm{Cbt} \rightarrow \mathrm{Iqx} \\
\mathrm{lq} x \rightarrow \mathrm{Cbt}\end{array}$ & $\begin{array}{l}23.211 \\
16.939\end{array}$ & $\begin{array}{l}(0.000) \\
(0.000)\end{array}$ & $\begin{array}{l}11.61 \\
8.469\end{array}$ & $\begin{array}{l}(0.000) \\
(0.000)\end{array}$ \\
\hline $\begin{array}{l}\text { Fed does not cause Cbt } \\
\text { Cbt does not cause Fed }\end{array}$ & $\begin{array}{c}7.2205^{*} \\
-0.0004\end{array}$ & $\begin{array}{c}16.840 \\
0.0003\end{array}$ & $\begin{array}{l}\text { Fed } \rightarrow \text { Cbt } \\
\text { no causality }\end{array}$ & $\begin{array}{c}16.973 \\
0.2040\end{array}$ & $\begin{array}{l}(0.000) \\
(0.903)\end{array}$ & $\begin{array}{l}8.486 \\
0.102\end{array}$ & $\begin{array}{l}(0.000) \\
(0.903)\end{array}$ \\
\hline $\begin{array}{l}\text { Elc does not cause lo } \\
\text { lo does not cause Elc }\end{array}$ & $\begin{array}{l}-0.027 \\
0.1275\end{array}$ & $\begin{array}{l}0.0538 \\
0.1161\end{array}$ & $\begin{array}{l}\text { no causality/ } \\
\text { cointegration }\end{array}$ & $\begin{array}{l}0.311 \\
3.56\end{array}$ & $\begin{array}{l}(0.856) \\
(0.168)\end{array}$ & $\begin{array}{l}0.155 \\
0.178\end{array}$ & $\begin{array}{l}(0.85) \\
(0.170)\end{array}$ \\
\hline
\end{tabular}

Note: ${ }^{*},{ }^{* *}$ denotes significance at $0.05 \%$ and $0.01 \%$ respectively.

The long-run Wald test result presented in Tab. 7 reveals that $C b t$, Iqx, and Cbi formulas are significant as the explanatory variables lo, Cbt, Cbi, Elc, Iqx, and Rpi jointly flows to determine the three variables independently in the long-run, while the Io, Fed, Elec and Rpi formulas are insignificant. The result suggests that the long-term industrial output (lo) growth is weak since critical investment multiplier variables like energy $(E / C)$, real per capita income (Rpi) and human capital (Fed) are susceptible in the long-term. It appears that Africa presents a novel case or it still has some distance to cover to mature.

\section{Diagnostic Tests}

\section{VAR Residual Serial Correlation LM test}

The result of the serial correlation test, which is a pre-condition for the methodology applied, suggests a lack of serial correlation at lag order 2 as shown in Tab. 8.

\section{Pedroni's Co-integration Test}

Being heterogeneous panel with considerable amount of non-stationary variables, the study applied the Pedroni cointegration test for the existence of co-integration (Pedroni, 2000; Asteriou \& Hall, 2011). The result is presented in Tab. 9. The result suggests that co-integration

\section{Tab. 7: Long-run causality results: joint statistics modified Wald test}

\begin{tabular}{|c|c|c|c|c|c|}
\hline $\begin{array}{c}\text { Variables studied at lag } \\
\text { order } \mathrm{P}=2 \text { : Io, Cbt, Elc, } \\
\text { Fed, Iqx, Rpi, Cbi }\end{array}$ & $\chi^{2}$ stat. & F-stat. & $\begin{array}{l}\text { Prob. } \\
\left(\chi^{2} \text { stat.) }\right.\end{array}$ & $\begin{array}{l}\text { Prob. } \\
\text { (F-stat.) }\end{array}$ & $\begin{array}{l}\text { Outcome: joint } \\
\text { influence flow }\end{array}$ \\
\hline Dependent variable: lo & 10.3205 & 1.4750 & 0.1709 & 0.1764 & No \\
\hline Dependent variable: $\mathrm{Cbt}$ & $18.5298^{* \star}$ & $2.6471^{*}$ & 0.0098 & 0.0117 & Yes \\
\hline Dependent variable: Elc & 7.4988 & 1.0713 & 0.3788 & 0.3823 & No \\
\hline Dependent variable: Fed & 5.9499 & 0.8499 & 0.5456 & 0.5459 & No \\
\hline Dependent variable: Iqx & $29.740^{* *}$ & $4.248^{* *}$ & 0.0001 & 0.0002 & Yes \\
\hline Dependent variable: Rpi & 6.6424 & 0.948 & 0.4670 & 0.4693 & No \\
\hline Dependent variable: $\mathrm{Cbi}$ & $16.839^{*}$ & $2.4056^{*}$ & 0.0185 & 0.0211 & Yes \\
\hline
\end{tabular}


Tab. 8: Serial correlation LM test

\begin{tabular}{c|c|c|c|c|c|c} 
Lag & LRE* $^{*}$ stat. & Df & Prob. & Rao F-stat. & Df & Prob. \\
\hline 1 & 106.568 & 49 & 0.0000 & 2.2171 & $49,1532.5$ & 0.0000 \\
\hline 2 & $63.674^{*}$ & 49 & 0.0776 & $1.3064^{*}$ & $49,1532.5$ & 0.0776 \\
\hline
\end{tabular}

Source: own

Note: ${ }^{*}$ indicates significance at 0.05 .

Tab. 9: Pedroni residual cointegration test

\begin{tabular}{l|c|c|c|c|c|c} 
& $\begin{array}{c}\text { Trend } \\
\text { assumption }\end{array}$ & AR. Coeff. & Statistics & Prob. & $\begin{array}{c}\text { Weighted } \\
\text { stat. }\end{array}$ & Prob. \\
\hline Panel PP-Stat. & No trend & Common & $-8.2342^{*}$ & 0.000 & $-6.9956^{*}$ & 0.000 \\
\hline Panel ADF-Stat. & No trend & Common & $-3.8555^{*}$ & 0.000 & $-2.5407^{*}$ & 0.005 \\
\hline Group PP-Stat. & No trend & Individual & $-12.563^{*}$ & 0.000 & - & - \\
\hline
\end{tabular}

Source: own

Note: ${ }^{*}$ indicates significance at 0.01 .

exists among the variables under study as the probability value that co-integration does not exist is less than $10 \%$.

\section{Model Stability Test}

An examination of the model stability structure reveals that the variables under study are centrally located within the unit circle, which suggests the absence of unit root; therefore, the condition for stability of the model is met.

\subsection{Main Findings}

The hypothesis seeks to establish if the secondary market information on liquidity has added value (signaling effects) for real investment. In the short-run dynamic causality result only one variable-corporate bond turnover (Cbt) achieved the required negative residual coefficient, and may indicate a tenuous relationship between the financial sector and the real sector, as the variables exhibit instability and explosion in the long-run. Central to the findings of the study is that no long-run joint or one-way causal flow is achieved from the $\mathrm{Cbt}$ to $l o$. That is, against the theoretical literature, market liquidity does not have signaling effect on real investment in African economies. This output may be informed by the low trading capacities of the corporate bond markets in most of the economies, except South Africa and perhaps Mauritius (see Fig. 1), since the quantity of issues are relatively low compared to other economic blocks. The liquidity signaling effect is however found to share positive influence with regulatory institutional quality (Iqx). The long-term effect is that quality of the regulatory institutions can assist through effective policies to boost the issue market, with possible spillover to the bond market. The longrun, results however show that corporate bond turnover (Cbt) does not cause corporate bond issue (Cbi); while corporate bond issue (Cbi) does not cause industrial output (Io) growth, which suggest that the continent relies more on the money market (short-term) instruments to fund industrial output. Money market as means of industrial finance may be unsustainable, due to high interest cost and implicit mismatch.

In addition, the study finds that electricity consumption $(E / C)$ does not cause industrial output (Io) which suggests poor electricity supply gap suffices for industrial usage as being experienced in many African economies such as in Nigeria. While human capital development proxied by financial education ( $F e d$ ) causes market turnover, a mirror of market activities and awareness of bond investments. However, market turnover have negative causal relations with financial education, contrary to what economic theory would suggest, that bond trading activities can provide financial information and hence education platform for investors and the citizens. 


\section{Discussion of Findings}

Transactions in corporate bonds makes such bonds increasingly liquid which is a plus to the corporate finance structure of the issuer. This could raise awareness to attract raising more but less expensive capital to increase production and expansion. The findings of the study enables the failure to reject the null hypothesis on the secondary corporate bond turnover (Cbt) (proxy for bond market liquidity), signaling to industrial output (lo) and investment. The outcome proves contrary to findings in some earlier contemporary works, particularly in the equity market. Nevertheless, the lack of relationship between the secondary bond market (liquidity) on one hand and corporate bond issue market on the other imply liquidity risk of the corporate bond investment resulting in buy and hold attitude of investors in the bond market, as also often experienced in many of continent's equity markets. Furthermore, the lack of a link from the secondary market to the industrial output would indicate lack of information flow to the market and necessary feedback from activity of industrial output growth.

Both the issue and secondary markets should be mirror image of themselves. The issue market requires the information from the secondary market for various purposes, such as access to the stock trading performance, industry performance, potential issue price settings, competitive pricing and strategies to overcome competitors, and many more. On the other hand, market liquidity is often boosted by incentives from the offer (primary) market. The primary market needs more securities to be issued in order to deepen the market and open it for more breath and liquidity. Moreover, entrepreneurs with requisite and sound managerial skills may have to approach the market to offer their skills, raise capital and further diversify the risks in the market. This is the hallmark of the growing market system. The weak regression outcomes between the two markets may however not be unconnected with lack of protective laws on rights of private property, weak regulatory institutions, and poor state of the rule of law in developing markets.

The lack of linkage between the primary and secondary markets may have further stressed the underdeveloped nature of the corporate bond market, as the liquidity of the secondary market provides information on efficient pricing and traded volume. The two-way flow is important for financial and corresponding real sector growth. Therefore, it can be argued that industrial output growth which should be evidence of liquidity of the bond market suffers from the low perception of investors or lack of information of industrial activity to bond investors.

The study however, discovers that corporate bond market liquidity and institutional regulatory quality (Iqx) share significant positive relationship in the region, which brings to light the potencies and pervasive influence of liquidity in the long tenured markets. The primary function of the regulatory institution (the SECs) and other self-regulatory institutions are for the creation of enabling environments for market participants. Additionally, the provisions of market infrastructure, stability of the markets, protection of investors, market transparency and efficiency infrastructural development should include trading facilities, information and data availability. Where these functions are not effectively managed, it might reduce patronage of the primary market and frustrate the secondary market, affect investors' morale and low liquidity might ensue. Harrison (2002) informs that severe liquidity shock is equally as bad as credit quality shock in the bond market, and is capable of widening the credit spread.

Liquidity signalling is capable of shutting firms out of the market, which can perpetuate market inactivity. As firms are unable to obtain investment funds, industrial productivity and growth rate declines, the effects transmits to rising unemployment level and low investment cycles. A highly deep and liquid (breath) market aside from helping to meet current capital needs of investors can serve as buffer and an instrument for market resilience during a period of financial market distress. The IOSCO (2002) argues that use of indirect monetary policy instrument such as open market operation is capable of improving patronage of secondary market trading in bonds.

Some potential factors that may have militated against the linkage of both markets and negatively impacts the corporate output growth, leading to underdeveloped corporate bond market, may not be unconnected to the weak market infrastructure; existence of few market intermediaries; higher interest issue cost and coupon rate; long offer circle period due to complex regulations (Tendulkar, 2015). Upon 
effective regulations, the growth of the pension fund and life insurance markets could provide support and can be a significant development partner for the liquidity needs in the secondary market. As investors, both institutions would now provide impetus on corporate governance in investee institutions. Increasing capital and investible funds base of the pension fund can serve other ancillary needs of the secondary market such as provision of sustainable investment fund.

The significant negative causal relations from the liquidity market to public financial education (Fed) runs contrary to financial markets dynamism and in particular economic development. It implies that the African financial market may be weak, thin and shallow. In developed financial markets, trading information serves as major source of resource allocation. Market activities and intermediary institutions are expected to be sources of information to existing and potential investors (Levine, 2004). Financial markets help to transmit information to firms and vice versa. They also provide investment information on risky projects as well as monitor investors' agents. Hence, in summary it serves to educate the financial system and provide information for industrial investment expansion and cost reduction.

\section{Conclusion and Recommendations}

The paper seeks to investigate if there is a functional link between bond market liquidity and industrial investment, a platform which the market can ignite new issues for industrial investments critical to industrial output growth in African economies. The study uses an augmented Toda-Yamamoto (ATY) framework to test the hypothesis in a panel study of thirteen African economies with data from 1995-2018. The short run dynamic results and the error correction mechanism (ECM) coefficients produce appropriate a priori signs, which reveals stability and co-integration for industrial output growth (lo), corporate bond turnover (Cbt), and corporate bond issue (Cbi) formulas. It suggests that the joint influence of all explanatory variables flow to these dependent variables and converges to equilibrium.

The long-run results however show that the market liquidity does not link to the corporate bond issue (Cbi). Similarly, the bond issue market does not link industrial output (Io) growth, which suggest that the continent relies more on the banking and money market instruments to fund industrial output. Electricity consumption $(E / C)$ does not cause industrial output (lo) which suggests low industrial output from high energy costs from alternative energy sources for industrial production. The test on secondary market liquidity linkage with industrial output reveals that there are no co-integrating relations between the secondary market and industrial output growth in the long term, which suggest that the market does not 'invest in risk information' for investors. However, study reveals that the bond market enhances institutional regulatory quality, needful for the development of the issue market.

The specific recommendations are as follows: Firstly, there is no significant bilateral or unilateral tie between corporate bond turnover (Cbt) and corporate bond issue (Cbi), which suggests that the markets are shallow and thin. The private industrial and non-finance corporates (NFC) need to be motivated to embrace bond financing for their operations and long-term investments. African governments are advised to concession fiscal incentives for this cause. Additionally, selfregulatory institutions should relax conditions for new bond issues and listing requirements to attract more entrants, particularly for small and medium scale enterprises (SMEs).

Secondly, corporate bond turnover (Cbt) positively and significantly influences regulatory quality (Iqx): market liquidity can be promoted to have positive influence on regulation by improving the financial market liberalization, where market is made to determine prices. African governments via their Securities and Exchange Commission (SEC) can help to promote private initiatives to establish market infrastructure and exchanges for secondary trading. There is the need to promote derivative exchanges across all African markets to give live and risk support to secondary market trading.

Thirdly, corporate bond turnover (Cbt) does not have functional link with industrial output (lo), which may imply that "market noise" does not transmit or influence the financing of capital investments, where cheap funds can be sourced, unlike the bank credit option. This study recommends greater awareness for corporate finance management to consider bond issues as alternative finance mix that is more long term and cheaper. 
Fourthly, corporate bond turnover (Cbt) have significant negative functional link with financial education, meaning that the market may not be providing public education on its activities as expected, hence low awareness, poor knowledge and investment education transmission to the corporate issue market. It is likely that bond trading activities may have been too elitist in African region. Market trading activities should be disseminated as means of education to the investing public and students in tertiary institutions. To ensure the larger public is informed, trading information can be transmitted through wider media coverage and in local languages. Stockholders associations should be established to promote good corporate governance and stock performance. Finally, provision of capital market infrastructures should be privatized with attractive fiscal incentives, such that the private sector can provide modern technology for the overall development of the capital markets.

Acknowledgement: The authors thank Covenant University for supporting the publication of this research financially.

\section{References}

Adebiyi, M. A. (2005). Financial Sector Reforms, Interest Rate Policy and the Nigerian Manufacturing Sub-sector. Paper presented at Nigerian Economic Society Annual Conference: Challenges of Nigerian Industrialization: A Partway to Nigeria Becoming a Highly Industrialized Country in the year 2015 (pp. 337-368).

Adetiloye, K. A., Taiwo, J. N., \& Duruji, M. M. (2017). Market Risk Instruments and Portfolio Inflows in African Frontier Economies. In Ü. Hacioğlu, \& H. Dinçer (Eds.), Global Financial Crisis and Its Ramifications on Capital Markets. Contributions to Economics (pp. 371-386). Cham: Springer. https://doi.org/10.1007/978-3319-47021-4 26

Adelegan, J. O., \& Razewicz-Bak, B. (2009). What Determines Bond Market Development in Sub-Saharan Africa? (IMF Working Paper WP/09/213). Washington, DC: International Monetary Fund. Retrieved from https://www. imf.org/external/pubs/ft/wp/2009/wp09213.pdf

Akinlo, A. E., \& Owoyemi, B. O. (2012). The Determinants of Interest Rate Spread in Nigeria: An Empirical Investigation. Modern
Economy, Scientific Research, 3(7), 837-845 https://doi.org/10.4236/me.2012.37107

Andriansyah, A., \& Messinis, G. (2014). Equity Market and Economic Development: Does the Primary Capital Market Matter? Economic Records, 90(S1), 127-141. https://doi.org/10.1111/1475-4932.12134

Arellano, M., \& Bond, S. (1991). Some tests of specification for panel data: Monte Carlo evidence and an application to employment formulas. Review of Economic Studies, 58(2), 277-297. https://doi.org/10.2307/2297968

ASEA. (2014). African Securities Exchange Association Annual Report and Statistics, 2014 Annual Report and Statistics. Retrieved May 12, 2016, from http://www.african-exchanges.org

ASEA. (2009). African Securities Exchange Association Year Book 2009. Retrieved August 13, 2016, from www. africansea.org

Assefa, T. A., \& Mollick, A. V., (2014). African stock market returns and liquidity premia. Journal of International Financial Markets, Institutions and Money, 32, 325-342. https://doi.org/10.1016/j.intfin.2014.06.009

Asogwa, R. C. (2005). Challenges of Industrialization Finance in Nigeria: Implementing Market-Based Financing options. Paper presented at Nigerian Economic Society Annual Conference: Challenges of Nigerian Industrialization: A Partway to Nigeria Becoming a Highly Industrialized Country in the year 2015 (pp. 553-577).

Asteriou, D., \& Hall, G. S. (2011). Applied Econometrics (2nd ed.). London: Palgrave Macmillan.

Ayala, D., Nedeljkovic, M., \& Saborowski, C. (2015). What Slice of the Pie? The Corporate Bond Market Boom in Emerging Economies. Journal of Financial Stability, 30, 16-35. https://doi.org/10.1016/j.jfs.2017.03.003

Bernanke, B. S., \& Blinder, A. S. (1988). Credit, Money, and Aggregate Demand. The American Economic Review, 78(2), 435-439.

Bernanke, B. S., \& Gertler, M. (1990). Financial Fragility and Economic Performance. Quarterly Journal of Economics, 105(1), 87-114. https://doi.org/10.2307/2937820

Bod'a, M., \& Zimková, E. (2018). Measuring Financial Intermediation: A Model and Application to the Slovak Banking Sector. E\&M Economics and Management, 21(3), 155-170. https://doi.org/10.15240/tul/001/2018-3-010

Bond, P., Edmans, A., \& Goldstein, I. (2012). The Real Effects of Financial Markets. 
Annual Review of Financial Economics, 4, 339-360. https://doi.org/10.1146/annurevfinancial-110311-101826

Cecchetti, G. S. (2008). Money, Banking and Financial Market (2nd ed.). New York, NY: McGraw-Hill Irwin.

Copeland, T. E., \& Weston, J. F. (1992). Financial Theory and Corporate Policy (3rd ed.). Boston, MA: Addison Wesley Publishing Company.

Darvas, Z. (2012). Real effective exchange rate for 178 countries: A new database (Working Paper 2012/06). Brussels: Bruegel.

Demirgüç-Kunt, A., \& Levine, R. (1996). Stock Markets, Corporate Finance, and Economic Growth: An Overview. The World Bank Economic Review, 10(2), 223-239. https://doi.org/10.1093/wber/10.2.223

Djankov, S., McLiesh, C., \& Shleifer, A. (2007). Private Credit in 129 Countries. Journal of Financial Economics, 84(2), 299-329. https://doi.org/10.1016/j.jfineco.2006.03.004

Eke, P. O., Adetiloye, K. A., Adegbite, E. O., \& Okoye, L. U. (2017). A co-integration analysis of interest rate spread and corporate bond market development in selected African economies. Journal of Applied Economic Sciences, 12(6), 1654-1667.

Eke, P. O., Adetiloye, K. A., \& Taiwo, J. N. (2018). Regulatory Institutional quality and long-run primary capital market development: the Nigerian case. Afro-Asian Journal of Finance and Accounting, 8(2), 167-189. https://doi.org/10.1504/AAJFA.2018.091064

Engle, R. F., \& Granger, C. W. J. (1987). Co-integration and Error Correction: Representation, Estimation, and Testing. Econometrica, 55(2), 251-276. https://doi. org/10.2307/1913236

Esqueda, O. A., Assefa, T. A., \& Mollick, A. V. (2012). Financial globalization and stock market risk. Journal of International Financial Markets Institutions and Money, 22(1), 87-102. https://doi.org/10.1016/j.intfin.2011.07.006

Finance Maps of World (FMW). (2013). Capital Market Theory. Retrieved July 11, 2015, from finance.mapofworld.com/capital market theory

Goldsmith, R. W. (1969). Financial Structure and Development. New Haven, CT: Yale University Press.

Goldstein, M. A., Hotchkiss, E. S., \& Pederson, D. J. (2019). Secondary Market Liquidity and Primary Market Pricing of Corporate Bonds. Journal of Risk and
Financial Management, 12(2), 86. https://doi. org/10.3390/jrfm12020086

Grishchenko, O., Zhaogang, S., \& Hao, Z. (2015). Term Structure of Interest Rates with Short-Run and Long-Run Risks (FEDS Working Paper No. 2015-95). Washington, DC: Federal Reserve Board.

Grossman, G. M., \& Helpman, E. (1994). Endogenous Innovation in the Theory of Growth. Journal of Economic Perspectives, 8(1), 23-44. https://doi.org/10.1257/jep.8.1.23

Harrison, P. (2002). The impact of Market Liquidity in times of stress on Corporate Bond Issuance. Paper presented at the BIS Third Joint Central Bank Conference on Risk Measurement and Systemic Risk (pp. 166179). Retrieved from https://www.bis.org/cgfs/ conf/mar02m.pdf

Hoschi, T., Kashyap, A., \& Schafstein, D. (1991). Corporate Structure, Liquidity, and investment: Evidence from Japanese Industrial Groups. The Quarterly Journal of Economics, 106(1), 33-60 https://doi.org/10.2307/2937905

Hye, Q. M. A., \& Raiz, S. (2008). Causality between Energy Consumption and Economic Growth: The Case of Pakistan. The Lahore Journal of Economics, 13(2), 45-58. https://doi. org/10.35536/lje.2008.v13.i2.a3

IOSCO. (2002). The development of corporate bond markets in emerging market countries. Madrid: International Organization of Securities Commission. Retrieved from iosco. org/library/pubdocs/pdf/IOSCOPD127.pdf

Kuyingi, S. (2010). Business Day Law Legal Insight: Insight from Outside. Retrieved from www.businessdayonline.com

Levine, R. (2004). Finance and Growth: Theory and Evidence (NBER Working Paper WP10766). Cambridge, MA: National Bureau of Economic Research. Retrieved from http://www.nber.org/papers/w10766.pdf

Mu, Y., Phelps, P., \& Stotsky, J. G. (2013). Bond markets in Africa. Review of Development Finance, 3(3), 121-135. https://doi.org/10.1016/j.rdf.2013.07.001

Mun Heng, T. (2015). Modern Economic Development Concepts. In M. Yülek (Ed.), Economic Planning and Industrial Policy in the Globalizing Economy. Public Administration, Governance and Globalization (Vol. 13, pp. 29-38). Cham: Springer. https://doi. org/10.1007/978-3-319-06474-1_2

Ojo, J. A. T. (2010). The Nigerian Maladapted Financial System: Reforming Task 
and Development Dilemma (1st ed.). Lagos: The CIBN Press Ltd.

Olowe, R. A. (2011). Financial Management: Concepts, Financial System and Business Finance (3rd ed.). Lagos: Brierly Jones Nigeria Limited.

Pack, H. (1994). Endogenous Growth Theory: Intellectual Appeal and Empirical Shortcomings. Journal of Economic Perspectives, 8(1), 55-72. Retrieved from https://www.jstor.org/stable/2138151

Patrick, H. T. (1966). Financial development and economic growth in underdeveloped countries. Economic Development and Cultural Change, 14(2), 174-189. Retrieved from https:// www.jstor.org/stable/1152568

Pedroni, P. (2000). Fully modified OLS for heterogeneous co-integrated panels. In $\mathrm{B}$. $\mathrm{H}$. Baltagi, T. B. Fomby, \& R. Carter Hill (Ed.), Nonstationary Panels, Panel Cointegration, and Dynamic Panels (Advances in Econometrics) (Vol. 15, pp. 93-130). Bingley: Emerald Group Publishing Limited. https://doi.org/10.1016/ S0731-9053(00)15004-2

Piljak, V., \& Swinkels, L. (2017). Frontier and emerging government bond markets. Emerging Markets Review, 30, 232-255. https://doi. org/10.1016/j.ememar.2015.10.002
Reichlin, P. (2004). Credit Market, Intermediation, and the Macroeconomy: A Discussion. In S. Bhattacharya, A. W. A. Boot, \& A. V. Thakor (Eds.), Credit, Intermediation, and the Macroeconomy, Models and Perspective (pp. 856-891). Oxford: Oxford University Press.

Sorensen, P. B., \& Whitta-Jacobsen, H. J. (2010). Introducing Advanced Macroeconomics: Growth and Business Cycles (2nd ed.). New York, NY: McGraw-Hill Higher Education.

Tendulkar, R. (2015). Corporate Bond Markets: An Emerging Markets perspective (Volume II, Staff Working Paper No. SWP6). Madrid: IOSCO. Retrieved from www.iosco.org/ library/pubdocs/pdf/IOSCOPD510.pdf

Van Horne, J. C., \& Dhamija, S. (2012). Financial Management and Policy (12th ed.). London: Pearson/Dorling Kindersley.

UNIDO. (2014). Inclusive and Sustainable Industrial Development: Creating Shared prosperity, Safeguarding the Environment. Vienna: UNIDO. Retrieved November 11, 2015, from www.unido.org

Wijst, N. V. D. (2013). Finance: A Quantitative Introduction. Cambridge: Cambridge University Press.

World Economic Forum (WEF). (2013). The Global Competitiveness Report 20132014 (Full data edition). Retrieved from www. weforum.org/gcr 